\title{
Antioxidant and anti-inflammatory activity of parts of Rhus javanica L.
}

\author{
Ji-Soo Choi ${ }^{1} \cdot$ Sang-Don Han ${ }^{1}$ - Tae-Won Jang ${ }^{2} \cdot$ Seung-Hyun Lee ${ }^{3}$. \\ Jae-Ho Park ${ }^{1}$ (iD
}

\section{붉나무의 부위 별 항산화 및 항염증 활성}

최지수 ${ }^{1} \cdot$ 한상돈 $^{1} \cdot$ 장태원 $^{2} \cdot$ 이숭현 $^{3} \cdot$ 박재호 $^{1}$

Received: 19 April 2019 / Accepted: 23 May 2019 / Published Online: 30 June 2019

(C) The Korean Society for Applied Biological Chemistry 2019

\begin{abstract}
Rhus javanica L. is Anacardiaceae plant distributed in East Asia. We evaluated the antioxidant activity and antiinflammatory effect of leaf, branch, root of ethyl acetate fraction from $R$. javanica. To confirm effective each extraction, The antioxidant activity was evaluated using 1,1-Diphenyl-2-picrylhydrazyl and 2,2'-azinobis(3-ethylbenzothiazoline-6-sulfonic acid) scavenging activity assays, and the anti-inflammatory activity was evaluated based on inhibitory activities on the protein and mRNA expression of iNOS and COX-2 in LPS-induced RAW264.7 cells. The phenolic compounds content of each extract was analyzed with Folin reagents and HPLC/PDA method. The gallic acids were identified and quantified. The roots of $R$. javanica showed strong antioxidant activity. Its total phenolic compounds content were higher than the orders. In addition, anti-inflammatory activity inhibited the protein and mRNA expression of nitric oxide production factor, following the same pattern as contents of phenolic compounds included gallic acid and its antioxidant
\end{abstract}

Jae-Ho Park $(\square)$

E-mail:parkjh@jwu.ac.kr

${ }^{1}$ Department of Medicinal Plant Science, Jungwon University, Goesan 28024, Republic of Korea

${ }^{2}$ Department of Medicinal Plant Resources, Andong National University, Andong 36729, Republic of Korea

${ }^{3}$ Industry-Academic Cooperation Foundation, Jungwon University, Goesan 28024, Republic of Korea

This is an Open Access article distributed under the terms of the Creative Commons Attribution Non-Commercial License (http://creativecommons. org/licenses/by-nc/3.0/) which permits unrestricted non-commercial use, distribution, and reproduction in any medium, provided the original work is properly cited. activity. In conclusion, $R$. javanica showed effective antioxidant and anti-inflammatory activity. Especially, the roots were evaluated to be highly valuable as a natural resource for reducing inflammation.

Keywords Antioxidant - Inducible nitric oxide synthase · Phenolic compounds $\cdot$ Rhus javanica

\section{서 론}

활성산소종(reactive oxygen species)은 전자 운반 과정 중 불완 전하게 환원된 전자나 cytokine 등 다양한 요인에 의해 생성된 다. 활성산소종은 생체 내에서 산화를 일으켜 질병을 초래하는 작용을 하며[1], 노화와 성인병뿐만 아니라 다양한 질병의 원인 이 된다[2]. 따라서 이러한 활성산소종에 의한 산화 작용으로부 터 생체를 보호할 수 있는 항산화제에 대한 연구들이 활발히 진행되고 있으며, 천연물에서 유래하는 천연 항산화제에 대한 연구가 주목받고 있다. 그 중에서, 식물 화학물질(phytochemicals) 은 식물의 2차 대사산물에 의해 생성되며, phenolics 및 flavonoid 계통의 화합물로 알려져 있다[3]. 이 물질들은 화학적인 연쇄반 응을 통해 alkyl radical 또는 alkylperoxy radical에 수소를 공 여하여, radical을 안정화해 제거함으로써 항산화 활성뿐 만 아 니라 항암, 항염증 활성 등을 포함한 다양한 약리작용을 통해 체내 활성산소 제어에 도움을 준다[4,5]. 인체의 염증반응은 인 체의 생체조직을 방어하기 위한 기전으로 정상적인 염증반응은 시간의 경과에 따라 염증 촉진성 매개체(pro-inflammatory mediators)의 생성은 감소되고, 항염증성 매개체(anti-inflammatory mediators)는 증가됨으로써 염증반응이 스스로 제한되는 조절과 정을 가지고 있다[6]. 염증 반응의 산물인 Nitric oxide (NO)는 
$\mathrm{NO}$ synthases (NOS)에 의해 생성되며, 면역과 염증반응에서 중 요한 분자로 알려져 있다[7]. Inducible NOS (iNOS)는 염증 환 경에서 대식세포에서 발현되며[8], iNOS는 정상 상태에서는 발 현되지 않으나 LPS 등에 의해서 발현이 유도되면 다량의 $\mathrm{NO}$ 를 생성하거나 prostaglandin E2, tumor necrosis factor- $\alpha$ 등과 같은 염증발현 중개 물질이 발생 된다[9-11]. 결과적으로, iNOS 에 의해 과발현된 $\mathrm{NO}$ 에 의해 만성적인 염증 및 다양한 질병이 발생한다. 이에 iNOS와 $\mathrm{NO}$ 생성의 억제는 염증 질환의 치료 에 매우 중요하다[12,13]. 따라서 염증성 매개체들의 생성을 억 제하거나 염증발현 중개 물질등을 억제하는 천연 유래 화합물 의 탐색은 부작용이 적은 항염증 치료제 개발을 위한 방편으로 주목받고 있다. 옻나무과에 속하는 붉나무(Rhus javanica L.)는 한국, 중국, 일본을 포함하는 동아시아에 널리 분포하며, 이질 및 설사 치료를 위한 전통 약재로 사용되어 왔다[14]. 붉나무는 gallic acid, gallotannins, phenolic acids, triterpenoids 및 flavonoids 등의 다양한 생리활성을 가지고 있다고 알려져 있으며[14-17]. 이러한 생리활성 물질에 의해 항산화 활성 $[18,19]$ 및 항염증 활 성[20]이 있다고 밝혀져 있다. 본 연구는 붉나무 잎, 줄기, 뿌리 에틸아세테이트 분획물의 항산화 활성 및 항염증 활성을 비교 분석하였다. 또한 HPLC/PDA 분석을 통해 활성 물질의 함량의 분석을 통해 붉나무의 부위 별 생리활성과 활성물질 간의 상관 관계를 비교 분석 하였다.

\section{재료 및 방법}

\section{실험재료}

본 연구에 사용된 붉나무(Rhus javanica)는 충북 괴산군 청천면 거봉리에서 채취하였고, 중원대학교 생약자원개발학과에서 건조 및 동정하여 시료로 사용하였다. 본 연구에 사용된 highperformance liquid chromatography grade의 methanol, petroleum ether, ethyl acetate, chloroform, acetonitrile, dimethyl sulfoxide 는 Merck (Frankfurter, Darmstadt, Germany) 제품을 사용하였 다. 세포배양 및 실험을 위한 Dulbecco's modified Eagle's medium (DMEM), fetal bovine serum, penicillin/streptomycin, trypsin은 Hyclone (Logan, UT, USA) 제품을 사용하였다. 나머 지 시약은 Sigma-Aldrich (St. Louis, MO, USA) 제품을 사용 하였다. 모든 항체는 abcam (Cambrige, MA, USA)의 제품을 사용하였다. 기타시약 및 기기는 별도 표기하였다.

\section{시료 추출 및 용매 분흭}

붉나무의 잎, 줄기, 뿌리 에틸아세테이트 분획물은 각 건조 시료 $500 \mathrm{~g}$ 을 분쇄한 후, $80 \%$ methanol $500 \mathrm{~mL}$ 로 7일간 침지한 후 Whatman filter paper (GE Healthcare Life Sciences, Amersham Place, Little Chalfont, Buckinghamshire, England)로 여과하였다. 메탄올 추출물을 $40{ }^{\circ} \mathrm{C}$ 이하의 중탕에서 감압 환류 냉각장치 $(\mathrm{N}$ $1110 \mathrm{~S}, \mathrm{EYELA}$, Tokyo, JAPAN)로 농축한 후 분별 깔대기를 이 용하여 petroleum ether, ethyl acetate 순으로 3 회 용매분획 하였 다. 수득한 에틸아세테이트 분획물을 감압 환류 냉각장치로 농축 하여 실험 전까지 $-27^{\circ} \mathrm{C}$ 에 보관하였고, dimethylsulfoxide으로 용 해하여 시료로 사용하였다. 붉나무 잎, 줄기, 뿌리 에틸아세테이 트 분획물의 수율은 각각 $2.8,1.1,2.2 \%$ 로 나타났다.

\section{$\mathrm{DPPH}$ 라디칼 소거활성}

1,1-Diphenyl-2-picryl-hydrazyl (DPPH)를 이용한 전자 공여능은 Bondet 방법[21]을 참고하여 측정하였다. $\mathrm{DPPH}$ solution은 $\mathrm{DPPH}$ 를 $515 \mathrm{~nm}$ 에서 흡광도 값이 1.00 이 되도록 에탄올을 이 용하여 희석 준비하였다. 각 농도 별 추출물 $(0.32,1.6,8,40$, $200 \mu \mathrm{g} / \mathrm{mL}$ )에 $\mathrm{DPPH}$ solution를 첨가한 후 $37^{\circ} \mathrm{C}$ 에서 20 분 반 응시켜 UV/Visible spectrophotometer (Human Cop, Xma$3000 \mathrm{PC}$, Seoul, Korea)를 이용하여 $515 \mathrm{~nm}$ 에서 흡광도를 측정 하였다.

DPPH radical scavenging activity (\%)

$$
=\left[1-\left(\mathrm{A}_{\text {Sample }}-\mathrm{A}_{\text {Blank }}\right) / \mathrm{A}_{\text {Control }}\right] \times 100
$$

'A $\mathrm{A}_{\text {Sample }}$ '=Absorbance values of DPPH radicals after treatment with sample.

'A $\mathrm{A}_{\text {Blank }}$ =Absorbance values of ethanol.

' $\mathrm{A}_{\text {Control }}=$ Absorbance values of DPPH radicals.

\section{ABTS 라디칼 소거활성}

$\mathrm{ABTS}$ 라디칼 소거 활성 능력은 Van den Berg 등의 방법[22] 을 참고하여 측정하였다. ABTS solution은 2,2'-azinobis(3ethylbenzothiazoline-6-sulfonic acid) diammonium salt와 potassium persulfate를 혼합하여 24시간 ABTS radical을 형성시킨 후 증 류수를 이용하여 $734 \mathrm{~nm}$ 에서 흡광도 값이 0.70 이 되도록 희석 하였다. 각 농도 별 추출물에 ABTS solution을 첨가한 후 37 ${ }^{\circ} \mathrm{C}$ 에서 20 분 반응시켜 UV/Visible spectrophotometer를 이용하 여 $734 \mathrm{~nm}$ 에서 흡광도를 측정하였다.

ABTS radical scavenging activity (\%)

$$
=\left[1-\left(\mathrm{A}_{\text {Sample }}-\mathrm{A}_{\text {Blank }}\right) / \mathrm{A}_{\text {Control }}\right] \times 100
$$

'A $\mathrm{A}_{\text {Sample }}=$ Absorbance values of ABTS radicals after treatment with sample.

'A $\mathrm{A}_{\text {Blank }}$ '=Absorbance values of $\mathrm{H}_{2} \mathrm{O}$.

'A $\mathrm{A}_{\text {Control }}=$ Absorbance values of ABTS radicals.

\section{Reducing Power}

Reducing power는 Oyaizu의 방법[23]을 참고하여 측정하였다. 각 농도 별 추출물 potassium phosphate buffer $(\mathrm{pH}$ 6.6)와 potassium hexacyanoferrate(III)를 혼합한 후, $50{ }^{\circ} \mathrm{C}$ 에서 20 분 반응시킨 후 찬물로 냉각 하여, trichloroacetic acid를 첨가하였 다. 위 반응액을 $2000 \mathrm{~g}$ 에서 5 분간 원심 분리하여 상등액에 증 류수와 ferric chloride를 첨가하여 혼합한 후, UV/Visible spectrophotometer를 이용하여 $700 \mathrm{~nm}$ 에서 흡광도를 측정하였다.

Reducing power (Relative value of $\mathrm{A}_{\text {Control }}, \%$ ) $=\left[\left(\mathrm{A}_{\text {Sample }}-\mathrm{A}_{\text {Blank }}\right) / \mathrm{A}_{\text {Control }}\right] \times 100$

'A $\mathrm{A}_{\text {Sample }}$ =Absorbance values of Reducing power after treatment with sample.

' $\mathrm{A}_{\text {Blank }}$ '=Absorbance values of $\mathrm{H}_{2} \mathrm{O}$.

' $\mathrm{A}_{\text {Control }}$ =Absorbance values of Reducing power after treatment with L-ascorbic acid. 


\section{총 페놀 함량 분석}

총 페놀 함량은 Folin-Denis 방법[24]을 참고하여 측정하였다. 추출물에 증류수, folin 시약을 혼합한 후, sodium carbonate를 넣어 40 분간 실온에서 반응시켰다. 수득한 상등액을 UV/Visible spectrophotometer를 이용하여 $725 \mathrm{~nm}$ 에서 흡광도를 측정하였다. 표준품은 tannic acid를 사용하였고, 정량 직선방정식을 사용하 였다.

\section{Gallic acid에 대한 HPLC 분석}

Gallic acid의 High performance liquid chromatography (HPLC) 분석은 Waters 2695 system과 Waters 2996 Photo diode detector를 통해 분석하였다. 실험에 사용된 시료는 메탄올에 용 해하여 $0.45 \mu \mathrm{m}$ membrane filter (Waters, Milford, MA, USA)를 이용해 여과하였고, 시료 $10 \mu \mathrm{L}$ 를 메탄올 및 $1 \%$ acetic acid $/ \mathrm{H}_{2} \mathrm{O}$ 을 이동상으로 Waters XBridge ${ }^{\mathrm{TM}} \mathrm{C}-18$ column $(4.6 \mathrm{~mm} \times 250 \mathrm{~mm})$ packed with $5.0 \mu \mathrm{m}$ diameter particles를 이용하여 흡광도 $271 \mathrm{~nm}$ 에서 분석하였다. 추출물의 gallic acid 는 표준품과 비교하여 동정 및 정량하였다.

\section{세포배양}

본 연구에 사용된 RAW264.7 세포는 American Type Culture Collection (ATCC, Manassas, VA, USA)에서 분양 받아 실험 하였다. 세포는 $1 \%$ penicillin/streptomycin 및 $10 \%$ fetal bovine serum이 포함된 $\mathrm{DMEM}$ 에서 $37^{\circ} \mathrm{C}, 5 \% \mathrm{CO}_{2}$ 조건하에 배양하였다.

\section{세포 생존율}

RAW264.7 세포를 24시간 배양한 후 농도 별로 시료를 처리하 였다. 시료 처리 24시간 후 alamarBlue ${ }^{\circledR}$ Cell Viability Reagent (Thermo Fisher Scientific, MA, USA)을 배지의 총량의 $10 \%$ 씩 처리하여 2시간 배양하였다. 반응 후 UV/Visible spectrophotometer을 이용하여 $570 \mathrm{~nm}$ 에서 흡광도를 측정하여 세포생 존율을 확인하였다.

\section{NO 생성량 측정}

RAW264.7 세포를 24시간 배양한 후 농도 별로 시료를 처리하 였다. 시료 처리 1시간 후 LPS를 처리하여 24시간 배양한 상 등액을 $\mathrm{NO}$ 생성량 측정에 사용하였다. 세포 상등액에 Griess reagent $\quad(1 \%$ sulfanilamide, $0.1 \% \quad \mathrm{~N}$-1-naphthylenediamine dihydrochloride, and $5 \%$ phosphoric acid)를 처리하여 $540 \mathrm{~nm}$ 에서 흡광도를 측정하였다.

\section{Immunoblotting}

RAW264.7 세포를 24시간 배양한 후 농도 별로 시료 및 LPS 를 처리하였다. 시료 처리 24시간 후 PBS로 두 번 세척한 후, protease inhibitor cocktail을 포함한 RIPA buffer로 용해한 후 얼음에서 30 분간 정치시켰다. 세포 용해액을 $4{ }^{\circ} \mathrm{C}, 12,000 \mathrm{rpm}$ 에서 20 분 간 원심분리하고, 상층액은 Bradford 시약(Bio-rad, California, CA, USA)을 이용하여 단백질 정량을 실시하였다. 세포 용해액은 $2 \times$ Lamilae buffer와 혼합하여 $95^{\circ} \mathrm{C}$ 에서 5 분간 가열 후 각 $20 \mu \mathrm{g}$ 단백질량에 해당하는 시료를 $10 \% \mathrm{SDS}-$ $\mathrm{PAGE}$ 에서 전기 영동하여 분리하였다. 전기 영동된 단백질은 polyvinylidene difluoride membrane 막에 옮겨 상온에서 1시간 동안 blocking (5\% skim milk in TBST) 하였다. 1차 항체를 $4{ }^{\circ} \mathrm{C}$ 에서 overnight 처리하였다. TBST로 세척하고, 2차 항체를 1 시간 동안 반응시켰다. TBST로 세척하고 enhanced chemiluminescence western blotting detection kit (Bio-rad)로 반응하였다. 단백질 밴드는 ChemiDoc (Bio-rad)로 촬영하여 확 인하였다.

\section{Total RNA 추출 및 cDNA 합성}

RAW264.7 세포를 24시간 배양한 후 농도 별로 시료를 처리했 다. 시료 처리 48시간 후 PBS로 세척한 후, RNeasy ${ }^{\circledR}$ Plus Mini Kit (Qiagen, Hilden, Germany)를 이용하여 total RNA를 얻었다. 모든 과정은 $4{ }^{\circ} \mathrm{C}$ 에서 진행되었으며, Quantus fluorometer RNA system (Promega, Madison, WI, USA)를 사용하여 정량 하였으며, cDNA 합성을 위해 $1 \mu \mathrm{g}$ 의 total $\mathrm{RNA}$ 를 사용하여 ReverTra Ace - $\alpha$-(Toyobo, Osaka, Japan)를 이용하여 cDNA 를 합성하였다.

\section{RT-PCR}

cDNA상의 타겟 유전자를 증폭시키기 위하여 Quick Taq ${ }^{\circledR} \mathrm{HS}$ Dye Mix (Toyobo, Osaka, Japan)와 합성한 cDNA, forward primer와 reverse primer로 $\mathrm{PCR}$ 을 수행하였다. $\mathrm{PCR}$ 의 조건은 다음과 같다. $94{ }^{\circ} \mathrm{C}$ 로 2 분 간 denaturation을 시킨 후, $94{ }^{\circ} \mathrm{C}$ 에 서 30 초 간 denaturation 후 각 $\mathrm{Tm}$ 값에 맞추어 30 초 간 annealing, $68^{\circ} \mathrm{C}$ 에서 1 분 간 extension을 30 cycle 반복하였고 마지막 단계로 $72{ }^{\circ} \mathrm{C}$ 에서 10 분 간 extension하였다. House keeping gene으로 $\mathrm{GADPH}$ 을 사용하였고 $2 \%$ agarose gel (Affymetrix, Cleveland, OH, USA)로 UV상에서 band를 ChemiDoc (Bio-rad)로 확인하였다. 각 primer의 서열은 다음과 같다.

iNOS forward 5'-AAT GGC AAC ATC AGG TCG GCC ATC ACT-3', reverse 5'-GCT GTG TGT CAC AGA AGT CTC GAA CTC-3'.

COX-2 forward 5'-GGA GAG ACT ATC AAG ATA GT3', reverse 5'-ATG GTC AGT AGA CTT TTA CA-3'.

GADPH forward 5'-AAC TTT GGC ATT GTG GAA GG-3', Reverse 5'-ATG CAG GGA TGA TGT TCT GG-3'.

\section{통계학적 분석}

모든 실험은 3 번 이상 수행하였으며, 통계분석은 SPSS 18.0 (Statistical Package for the Social Sciences)을 이용하여 각 실 험의 평균과 표준편차를 계산하였고, one-way analysis of variance (ANOVA)로 분석하였다. 그룹 간 비교는 Student's ttest를 통해, $p>0.05$ 수준에서 *로 표기하였다.

\section{결 과}

\section{항산화 활성}

항산화 활성을 평가하기 위해 $\mathrm{DPPH}$ 라디칼 소거활성, $\mathrm{ABTS}$ 라디칼 소거활성 및 환원력을 평가하였다. 붉나무 에틸아세테이 트 분획물의 DPPH 라디칼 소거활성을 측정한 결과(Fig. 1A), 붉나무 잎, 줄기, 뿌리 에틸아세테이트 분획물의 농도가 높을수 

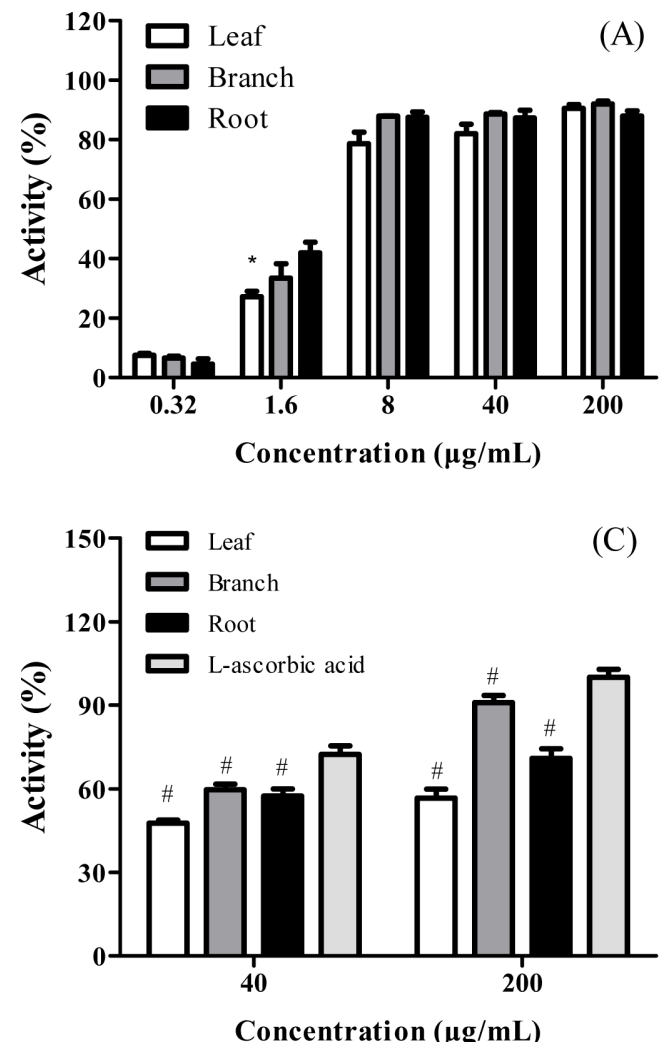

록 $\mathrm{DPPH}$ 소거 활성이 높았다. 붉나무 잎 에틸아세테이트 분획 물 각 농도 $(0.32,1.6,8,40,200 \mu \mathrm{g} / \mathrm{mL})$ 에서 $7.6 \pm 0.5,27.2 \pm 1.8$, $78.7 \pm 3.9,82.1 \pm 3.2,90.5 \pm 1.3 \%$ 로 나타났다. 붉나무 줄기 에틸아 세테이트 분획물 각 농도에서 $6.7 \pm 0.6,33.4 \pm 4.9,87.9 \pm 0.1$, $88.7 \pm 0.5,92.0 \pm 1.0 \%$ 로 나타났다. 붉나무 뿌리 에틸아세테이트 분획물 각 농도에서 $4.6 \pm 1.7,41.9 \pm 3.6,87.3 \pm 1.8,87.5 \pm 2.6$, $87.9 \pm 1.8 \%$ 로 나타났다. 붉나무 에틸아세테이트 분획물의 $\mathrm{ABTS}$ 라디칼 소거활성을 측정한 결과(Fig. 1B), 붉나무 잎, 줄기, 뿌 리 에틸아세테이트 분획물의 농도가 높을수록 $\mathrm{ABTS}$ 소거 활 성이 높았다. 붉나무 잎 에틸아세테이트 분획물 각 농도에서 $12.5 \pm 2.5,43.2 \pm 3.4,96.9 \pm 1.1,99.6 \pm 1.5,99.9 \pm 1.2 \%$ 로 나타났다. 붉나무 줄기 에틸아세테이트 분획물 각 농도에서 $1.49 \pm 1.9$, $52.3 \pm 2.9,97.2 \pm 0.5,99.7 \pm 0.7,99.8 \pm 0.7 \%$ 로 나타났다. 붉나무 뿌리 에틸아세테이트 분획물 각 농도에서 $15.7 \pm 1.5,69.7 \pm 3.3$, $98.8 \pm 0.3,99.8 \pm 0.8,99.9 \pm 1.0 \%$ 로 나타났다.

붉나무 에틸아세테이트 분획물의 환원력을 측정한 결과(Fig. 1C), 붉나무 잎, 줄기, 뿌리 에틸아세테이트 분획물의 농도가 높 을수록 환원력이 높았다. 환원력은 L-ascorbic acid와 비교하였 으며, 시료 농도 $200 \mu \mathrm{g} / \mathrm{mL}$ 를 100 으로하여 상대적인 값으로 표 현하였다. 붉나무 잎 에틸아세테이트 분획물 농도 $(40,200 \mu \mathrm{g} /$ $\mathrm{mL})$ 에서 $47.6 \pm 1.2,56.7 \pm 3.2 \%$ 로 나타났다. 붉나무 줄기 에틸아 세테이트 분획물 농도 $(40,200 \mu \mathrm{g} / \mathrm{mL})$ 에서 $59.6 \pm 2.1,91.0 \pm 2.6 \%$ 로 나타났다. 붉나무 뿌리 에틸아세테이트 분획물 농도 $(40,200$ $\mu \mathrm{g} / \mathrm{mL}$ )에서 $57.4 \pm 2.6,71.0 \pm 3.4 \%$ 로 나타났다.

총 페놀 화합물 함량 및 HPLC를 통한 gallic acid 화합물 동정 붉나무 에틸아세테이트 분획물의 총 페놀류 화합물의 함량 및

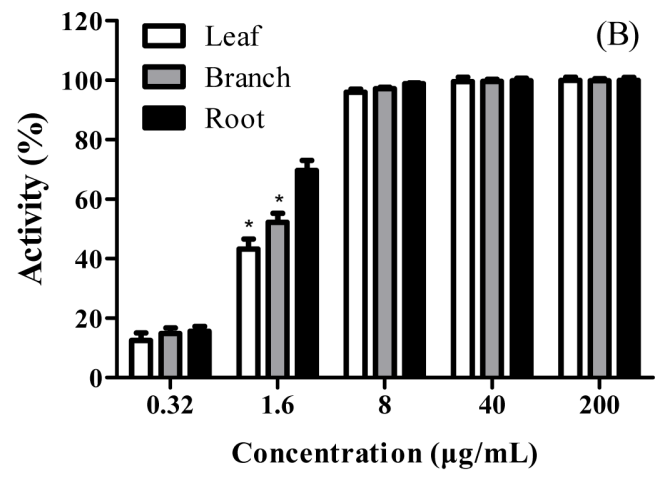

Fig. 1 Antioxidant activity of Rhus javanica L. (A) DPPH radical scavenging activity (\%) (B) ABTS radical scavenging activity (C) Reducing power (\% of L-ascorbic acid). All data are presented as means \pm SD. ${ }^{*} p<0.05$ compared to root. ${ }^{*} p<0.05$ compared to L-ascorbic acid

Table 1 Total phenolic compounds of Rhus javanica L.

\begin{tabular}{cccc}
\hline \hline Sample & Leaves & Branches & Roots \\
\hline $\begin{array}{c}\text { Total phenol content } \\
\text { (mg/g TAE) }\end{array}$ & $62.9 \pm 0.3$ & $70.3 \pm 0.4$ & $73.9 \pm 0.3$ \\
\hline
\end{tabular}

HPLC 분석을 통한 gallic acid 화합물의 분석 및 동정을 위해 표준품과 비교하여 정량 분석하였다. 총 페놀 함량을 확인하기 위해 농도 별로 희석한 tannic acid 표준품의 정량 곡선을 통해 환산하였다. 정량 곡선은 $\mathrm{y}=0.0127 \mathrm{x}+0.1012$ 로 나타났으며, 직 선성은 0.9884 였으며, 이를 통해 환산한 총 페놀 화합물의 함 량은 각각 $62.9,70.3,73.9 \mathrm{mg} / \mathrm{g}$ 으로 정량되었다(Table 1). 표준 품과 비교하여 $\mathrm{HPLC}$ 를 통한 gallic acid를 분석 및 동정한 결 과(Fig. 2), Choromatogram 상에서 retention time은 8.01분으 로 나타났으며 $210 \mathrm{~nm}$ 에서 $400 \mathrm{~nm}$ 의 spectrum 비교를 통해 gallic acid의 최대흡광도인 $271 \mathrm{~nm}$ 와 유사성을 확인하였으며, pattern의 유사성을 통해 gallic acid로 동정되었다. 표준품의 정 량 곡선은 $\mathrm{y}=25049 \mathrm{x}+36374$ 로 나타났으며, 직선성은 0.9981 였 으며, 이를 통해 붉나무 잎, 줄기, 뿌리 에틸아세테이트 분획물 에서 환산한 gallic acid의 함량은 각각 $21.5,30.6,27.7 \mathrm{mg} / \mathrm{g}$ 으 로 정량되었다.

\section{세포 생존율}

붉나무 잎, 줄기, 뿌리 에틸아세테이트 분획물의 세포 생존률을 확인한 결과(Fig. 3), 붉나무 잎, 줄기, 뿌리 에틸아세테이트 분 획물 $100 \mu \mathrm{g} / \mathrm{mL}$ 농도에서 $110.4 \pm 4.2,114.8 \pm 3.0,116.2 \pm 0.3 \%$ 로 나타났다. 따라서 붉나무 잎, 줄기, 뿌리 에틸아세테이트 분획 

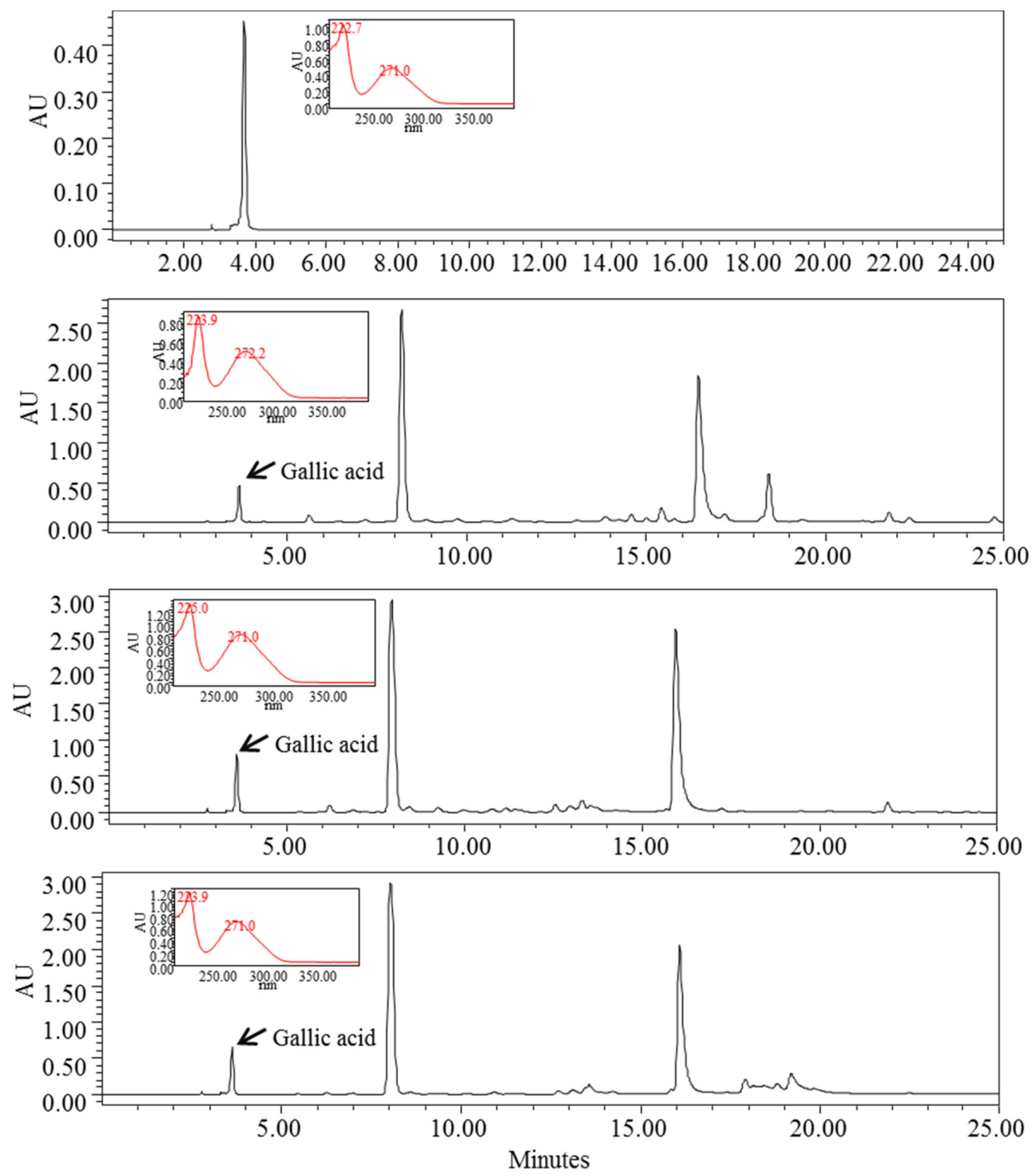

Fig. 2 Chromatogram of Rhus javanica L. in the identification by High performance liquid chromatography (HPLC). (A) Chromatogram and spectrum of gallic acid at UV $271 \mathrm{~nm}$ (B) Chromatogram and spectrum of leaf from Rhus javanica L. at UV $271 \mathrm{~nm}$ (C) Chromatogram and spectrum of branch from Rhus javanica L. at UV $271 \mathrm{~nm}$ (D) Chromatogram and spectrum of root from Rhus javanica L. at UV $271 \mathrm{~nm}$

물의 RAW264.7 세포에 대한 $100 \mu \mathrm{g} / \mathrm{mL}$ 이하 농도에서 시료 의 독성은 확인되지 않았다.

\section{항염증 활성}

항염증 활성을 확인하기 위해, Nitric oxide (NO) 생성량 확인 및 iNOS 및 COX-2 단백질 및 mRNA 수준을 확인하였다. 붉 나무 에틸아세테이트 분획물의 NO 수준을 확인한 결과(Fig. 4), LPS 처리에 의해 증가된 $\mathrm{NO}$ 는 처리된 시료에 의해 감소하였 다. 붉나무 에틸아세테이트 분획물 잎, 줄기, 뿌리의 $\mathrm{NO}$ 생성 량은 $449.1 \pm 5.3,222.2 \pm 1.0,208.0 \pm 0.9 \%$ 로 나타났다. 붉나무 에 틸아세테이트 분획물의 iNOS 및 COX-2 단백질 발현을 확인한 결과(Fig. 5), iNOS 단백질 발현은 모두 감소하였다. 잎, 줄기, 뿌리 처리군 각각 $\mathrm{iNOS}$ 발현량은 LPS 처리군 $(100 \%)$ 에 비해 $55.4 \pm 3.1,76.4 \pm 7.1,17.1 \pm 4.4 \%$ 로 나타났다. COX-2 단백질 발
현 또한 모두 감소하였다. 잎, 줄기, 뿌리 처리군 각각 $\mathrm{COX}-2$ 발현량은 $86.5 \pm 4.1,93.9 \pm 3.8,35.6 \pm 6.6 \%$ 로 나타났다. 붉나무 에 틸아세테이트 분획물의 $\mathrm{iNOS}$ 및 $\mathrm{COX}-2 \mathrm{mRNA}$ 발현을 확인 한 결과(Fig. 6), iNOS mRNA 발현은 잎과 뿌리 처리군에서 감소하였다. 잎, 줄기, 뿌리 처리군 각각 $\mathrm{iNOS}$ 발현량은 $92.6 \pm 2.2,110.2 \pm 1.1,37.4 \pm 4.8 \%$ 로 나타났다. COX-2 mRNA 발현 또한 모두 감소하였다. 잎, 줄기, 뿌리 처리군 각각 $\mathrm{COX}-$ 2 발현량은 $58.2 \pm 4.2,90.1 \pm 3.2,4.5 \pm 3.2 \%$ 로 나타났다.

\section{고 찰}

항산화 활성을 가지는 물질들은 세포 내 대사에서 발생하는 다 양한 전자 또는 산소, 수소 이온들을 제어한다. 세포는 활성 산 


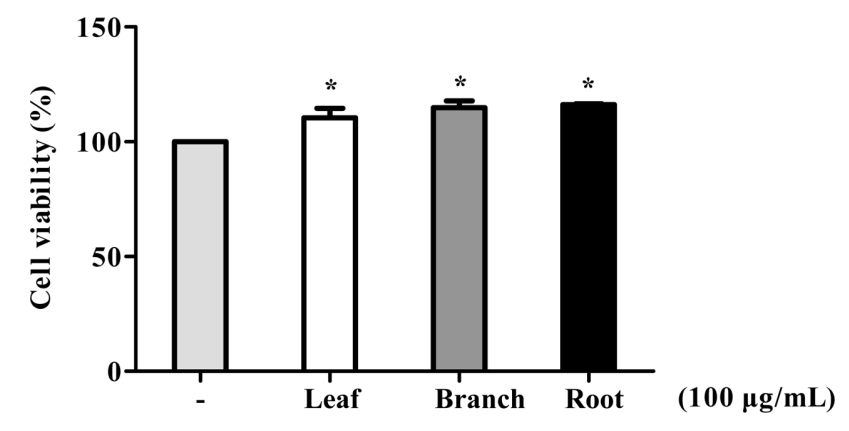

Fig. 3 Effect of Rhus javanica L. on cell viability. RAW264.7 cells were incubated with various concentrations of Rhus javanica L. $(100 \mu \mathrm{g} / \mathrm{mL})$ for $24 \mathrm{~h}$. Cell viability was determined by alamar blue reagents. All data are presented as means $\pm \mathrm{SD} .{ }^{*} p<0.05$ compared to non-treated control, which was set as $100 \%$

소종에 대한 방어 체계를 작동하여 세포 손상을 억제하고 산화 적 스트레스를 경감시킨다. 산화적 스트레스에 의해 손상된 인 체는 노화, 암, 다양한 병리적 증상에 이를 수 있다[1,2]. DPPH 및 $\mathrm{ABTS}$ 라디칼의 소거 활성 측정은 생리활성 물질의 항산화 활성을 측정하기 위해 널리 사용되는 방법이다[25]. 붉나무 에 틸아세테이트 분획물의 DPPH 라디칼에 대한 소거 활성은 항 산화 활성을 IC50 (Inhibitory Concentration 50\%)값으로 비교 한 결과, 잎 $(4.6 \mu \mathrm{g} / \mathrm{mL})$, 줄기 $(3.5 \mu \mathrm{g} / \mathrm{mL})$, 뿌리 $(3.2 \mu \mathrm{g} / \mathrm{mL})$ 로 나타났다. 또한 ABTS 라디칼에 대한 소거 활성을 IC50값으로 비교한 결과, 잎 $(1.6 \mu \mathrm{g} / \mathrm{mL})$, 줄기 $(1.3 \mu \mathrm{g} / \mathrm{mL})$, 뿌리 $(1.0 \mu \mathrm{g} / \mathrm{mL})$ 로 나타났다. 항산화 활성은 라디칼 소거 활성뿐만 아니라, 금 속 킬레이팅, 연쇄반응 억제, 환원력 등을 포함한다. 환원력은 항산화 활성을 가진 물질이 전자를 환원시켜 노란색의 화합물 이 초록 또는 청색으로 전환되는 작용을 이용한 것으로, 항산 화 활성을 확인하는 지표로 사용된다[26]. 환원력은 L-ascorbic

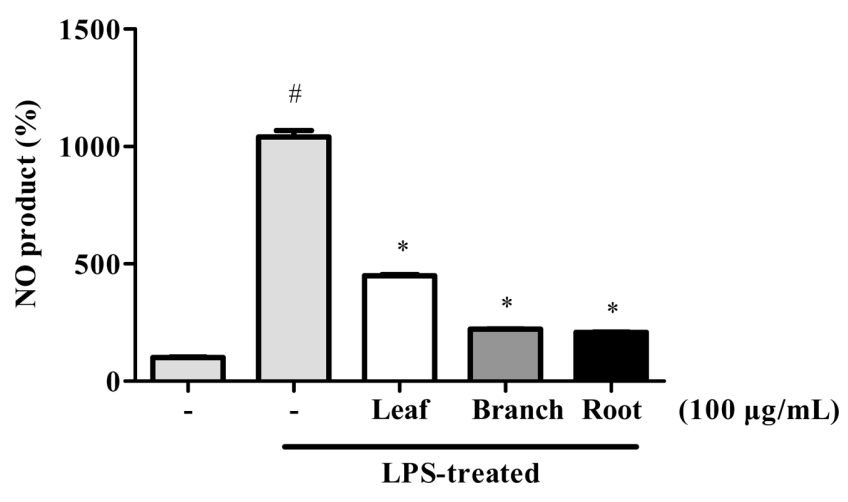

Fig. 4 The inhibitory effects on Nitric oxide (NO) products of Rhus javanica L. RAW264.7 cells were incubated with LPS and Rhus javanica L. $(100 \mu \mathrm{g} / \mathrm{mL})$ for $24 \mathrm{~h}$. NO products were evaluated by griess reagents. All data are presented as means \pm SD. ${ }^{\#} p<0.05$ compared to non-treated control. ${ }^{*} p<0.05$ compared to LPS-treated control

acid를 100 으로 하여 상대적인 값으로 나타내었으며, 그 활성은 줄기>뿌리>잎 순으로 나타났다. 이를 통해 라디칼 소거 활성 은 모든 부위의 활성이 뛰어났으나, 상대적으로 뿌리와 줄기에 서 높은 활성을 나타냈으며 환원력 또한 뿌리와 줄기에서 높은 활성을 나타내었다. 붉나무는 gallic acid를 비롯한 다양한 페놀 류 화합물을 포함하고 있으며 특히 gallic acid 및 그 유도체들 은 다양한 생리활성이 있다고 밝혀져 있다 $[15,17,18,20]$. 페놀류 화합물의 함량을 확인한 결과 잎, 줄기, 뿌리에서 각각 62.9 , $70.3,73.9 \mathrm{mg} / \mathrm{g}$ 으로 나타났다. 또한 gallic acid의 함량을 확인 하기 위해 HPLC/PDA 분석을 실시하였다. 표준품의 spetrum에 따른 absorbance pattern과 retention time을 비교 분석한 결과 gallic acid가 잎, 줄기, 뿌리에서 모두 동정되었다. 표준품의 정 량곡선과 비교 분석하여 정량한 결과, 잎, 줄기, 뿌리에서 21.5 ,
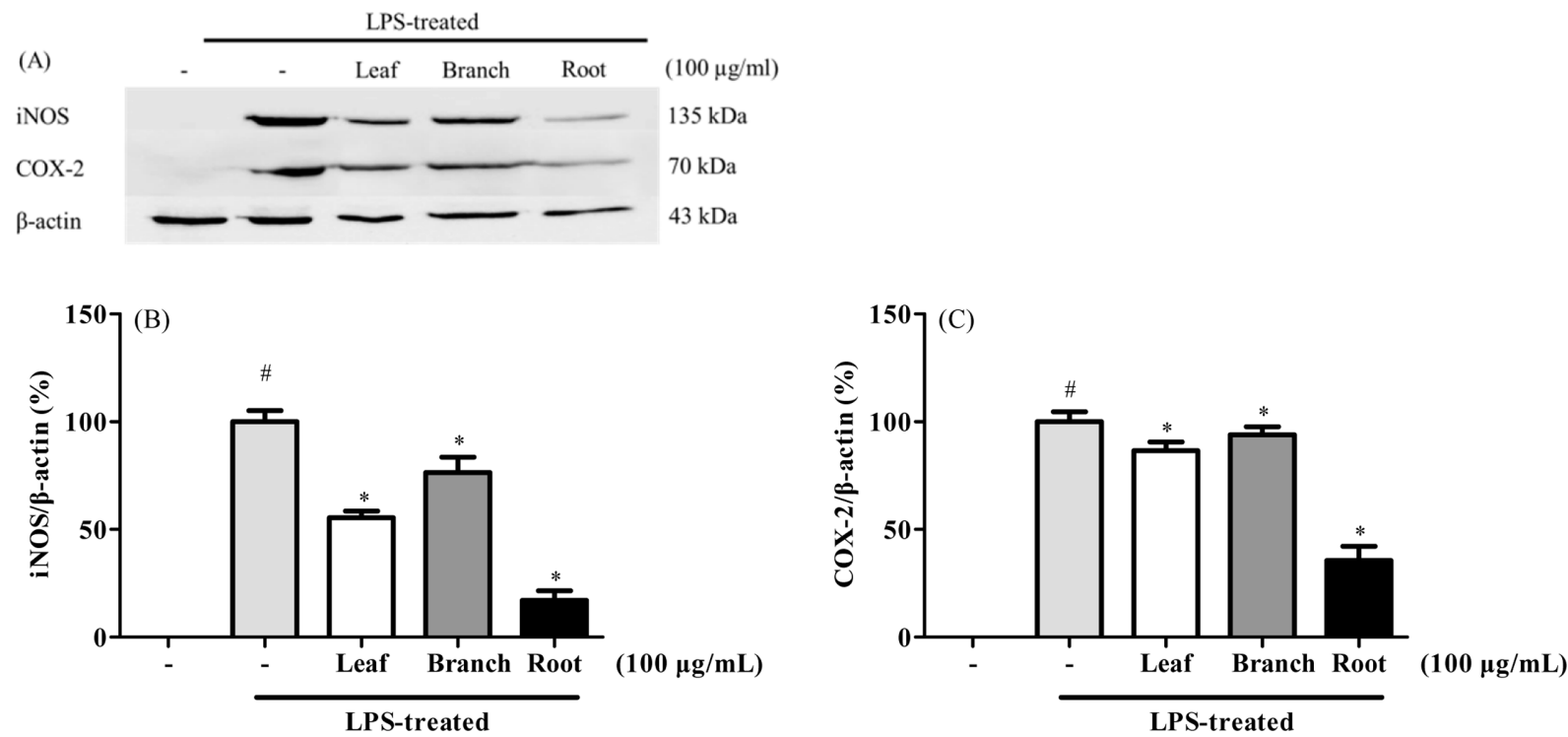

Fig. 5 Effect of Rhus javanica L on iNOS and COX-2 protein expression. (A) Immunoblot result of iNOS and COX-2 (B) iNOS/ $\beta$-actin expression of Rhus javanica L. (C) COX-2/ $\beta$-actin expression of Rhus javanica L. All data are presented as means \pm SD. ${ }^{*} p<0.05$ compared to non-treated control. ${ }^{*} p<0.05$ compared to LPS-treated control 

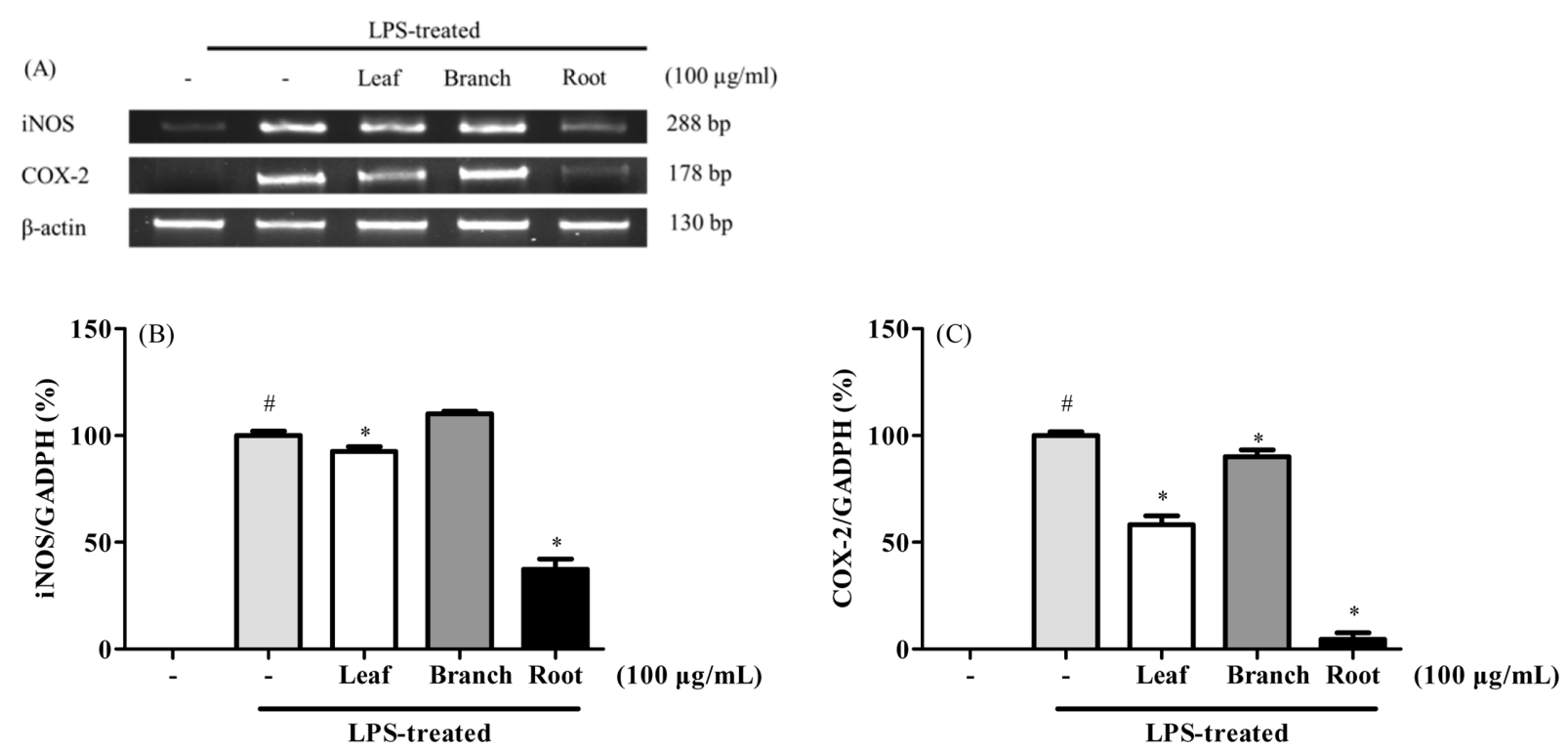

Fig. 6 Effect of Rhus javanica L on iNOS and COX-2 mRNA expression. (A) Electrophoresis result of iNOS and COX-2 mRNA expression (B) iNOS/GADPH expression of Rhus javanica L. (C) COX-2/GADPH expression of Rhus javanica L. All data are presented as means \pm SD. ${ }^{\sharp} p<0.05$ compared to non-treated control. ${ }^{*} p<0.05$ compared to LPS-treated control

$30.6,27.7 \mathrm{mg} / \mathrm{g}$ 로 나타났다. 이 결과, 높은 항산화 활성을 나타 낸 줄기 및 뿌리의 페놀류 화합물의 함량이 잎에 비해서 높았 으며, 그 지표성분으로 알려져 있는 gallic acid의 함량 또한 비 슷한 양상을 보였다. 이를 통해 붉나무의 항산화 활성과 페놀 류 화합물 및 gallic acid의 함량과는 밀접한 관련성을 가진다 고 사료된다. Pro-inflammatory cytokines, prostaglandin과 $\mathrm{NO}$ 생성은 LPS와 같은 물질에 의해 활성화된 대식세포에서 염증 반응에서 중요한 역할을 한다[27,28]. NO는 iNOS에 의해 Larginine으로부터 생성되며, 정상적인 상태에서는 혈관 확장, 면 역 반응, 신경 전달 등의 생리적인 기능을 조절하는 중요한 역 할을 한다[29,30]. 하지만 염증 반응에서 비정상적으로 과발현 된 $\mathrm{NO}$ 는 부종을 일으키고 염증 반응을 심화시켜 세포 및 조직 손상을 야기한다. 결과적으로 만성 염증 질환 및 자가면역질환 등을 발생시키게 된다[31]. $\mathrm{iNOS}$ 의 발현은 세균성 독소 또는 염증 및 산화성 스트레스, 면역반응, 조직손상 등에 따라 유리 되는 다양한 cytokine에 의해서 유전자 전사단계에 작용하게 된 다[32]. COX-2는 염증 반응을 포함하는 면역 반응에 관여하고, 염증성 cytokine이 분비되면 COX-2가 활성화된다[33]. 또한 $\mathrm{COX}-2$ 는 염증이 발생한 세포나 조직에서 과량의 prostaglandin 생성을 유도하여 혈관 생성을 촉진하고 세포의 증식을 도울 뿐 아니라 면역능력을 억제함으로써 암세포 성장에 좋은 환경을 제 공하여 COX-2의 발현은 종양 발생 및 발암과 같은 질병과 직 접적인 연관성을 나타낸다[34]. 본 연구에서 붉나무 에틸아세테 이트 분획물은 LPS로 활성화된 대식세포의 $\mathrm{NO}$ 생성을 억제하 는 것을 확인하였다. 또한 iNOS 단백질 발현 및 mRNA 수준 의 저해 효과를 확인하였으며, 뿌리의 항염증 효과는 잎과 줄 기에 비해 효과적이었다. 비록 잎의 항산화 활성 및 페놀류 화 합물의 함량은 상대적으로 낮았지만, 항염증 활성에서는 높은 활성을 나타냈다. 이를 통해 NO 생성의 저해는 iNOS 및 COX-2 발현의 억제로 야기되며 붉나무 에틸아세테이트 분획물
은 $\mathrm{NO}$ 생성에 직간접적으로 영향을 미쳤다. 또한 붉나무의 gallic acid를 비롯한 페놀화합물의 함량과 직접적인 상관관계가 있다고 사료된다. 이를 통해 붉나무 에틸아세테이트 분획물의 항염증 및 항산화 활성을 확인하였으며 결론적으로 뿌리의 생 리활성이 잎과 줄기의 생리활성에 비해 인체에 높은 효과를 나 타낼 것이라는 것을 확인하였다.

\section{초 록}

붉나무(Rhus javanica L.)는 동아시아에서 주로 분포하는 옻나 무과의 식물이다. 붉나무의 잎, 줄기, 뿌리 에틸아세테이트 분 획물의 항산화 활성 및 항염증 활성을 확인하였다. 붉나무 뿌 리 에틸아세테이트 분획물의 DPPH 및 ABTS radical 소거활성 이 가장 효과적이었으며, 총 페놀 화합물의 함량은 $62.9,70.3$, $73.9 \mathrm{mg} / \mathrm{g}$ 으로 나타났다. HPLC/PDA 분석을 통해 gallic acid를 동정 및 정량하였다. LPS로 자극시킨 RAW264.7 세포에서 항 염증 활성을 확인하였다. iNOS의 발현 억제를 통한 $\mathrm{NO}$ 생성 을 억제하였으며, 이러한 결과들을 통해 gallic acid를 포함하고 있는 붉나무는 염증 질환의 효과적인 경감 및 치료제로 개발될 수 있는 가능성을 보였으며, 붉나무 뿌리의 에틸아세테이트 분 획물의 활성이 잎과 줄기 에틸아세테이트 분획물의 활성보다 뛰 어났다.

Keywords Antioxidant - Inducible nitric oxide synthase Phenolic compounds · Rhus javanica

감사의 글 이 논문은 중원대학교 교내학술연구비 지원에 의한 것임(과제관 리번호: 2017-075) 


\section{References}

1. Maxwell SR (1995) Prospects for the use of antioxidant therapies. Drugs 49: 345-361

2. Marnett L (2000) Oxiradicals and DNA damage. Carcinogenesis 21: 361-370

3. Choe SY, Yang KH (1982) Toxicological studies of antioxidants butylated hydroxytoluene (BHT) and butylated hydroxyanisole (BHA) Kor J Food Sci Technol 14: 283-288

4. Asensi M, Ortega A, Mena S, Feddi F, Estrela JM (2011) Natural polyphenols in cancer therapy. Crit Rev Clin Lab Sci 48: 197-216

5. Lee YS, Joo EJ, Kim NW (2006) Polyphenol contents and antioxidant activity of Lepistanuda. J Kor Soc Food Sci Nutr 35: 1309-1314

6. Lawrence T, Willoughby DA, Gilroy DW (2002) Anti-inflammatory lipid mediators and insights into the resolution of inflammation. Nat Rev Immunol 2: 787-795

7. Guzik TJ, Korbut T, Admek-Guzik T (2003) Nitric oxide and superoxide in inflammation and immune regulation. J Physiol Pharmacol 54: 469487

8. Nathan C (1997) Perspective series: nitric oxide and nitric oxide synthases. J Clin Invest 100: 2417-2423

9. Choi DS (2009) Study on the antiinflammatory effect and mechanism of isoegomaketone in vitro and in vivo. Dissertation, Chonbuk National University

10. Chae CH (2004) Functional role of inducible nitric oxide synthase and cyclooxygenase-2 in acute inflammation. Ministry of Health and Welfare, Korea

11. Bak JP, Son JH, Kim YM, Jung JH, Leem KH, Lee EY, Kim EH (2011) Suppression effect of the inflammatory response in macrophages by Paeoniae Radix Rubra extracts. Kor J Med Crop Sci 19: 373-379

12. Aktan F (2004) iNOS-mediated nitric oxide production and its regulation. Life Sci 75: 639-653

13. Chen X, Tang SA, Lee E, Qiu Y, Wang R, Duan HQ, Dan S, Jin M, Kong D (2015) IVSE, isolated from Inula japonica, suppresses LPSinduced NO production via NF- $\mathrm{BB}$ and MAPK inactivation in RAW264.7 cells. Life Sci 124: 8-15

14. Lee IS, Oh SR, Ahn KS, Lee HK (2001) Semialactone, isofouquierone peroxide and fouquierone, three new dammarane triterpenes form Rhus javanica. Chem Pharm Bull 49: 1024-1026

15. Chung SC, Hwang BY, Oh GJ, Kang SJ, Kim MJ, Choi WH, Lee KS, Ro JS (1999) Chemical components from the stem bark of Rhus javanica L. Kor J Pharmacogn 30: 295-300

16. Oh JY, Choi U, Kim YS, Shin DH (2003) Isolation and identification of antioxidative components from bark of Rhus javanica Linne. Kor J Food Sci Technol 35: 726-732

17. Wang RR, Gu Q, Wang YH, Zhang XM, Yang LM, Zhou J, Chen JJ, Zheng YT (2008) Anti-HIV-1 activities of compounds isolated from the medicinal plant Rhus chinensis. J Ethnopharmacol 117: 249-256

18. Chun CS, Kim JH, Lim HA, Sohn HY, Son KH, Kim YK, Kim JS, Kwon CS (2004) Antioxidative effect of Rhus javanica Linne extract against hydrogen peroxide or menadione induced oxidative stress and DNA damage in HepG2 cells. J Food Sci Nutr 9: 150-155

19. Lin CN, Chen HL, Yen MH (2008) Flavonoids with DNA strandscission activity from Rhus javanica var. roxburghiana. Fitoterapia 79
32-36

20. Kim SH, Park HH, Lee SY, Jun CD, Choi BJ, Kim SY, Kim SH, Kim DK, Park JS, Chae BS (2005) The antianaphylactic effect of the gallo of Rhus javanica is mediated through inhibition of histamine release and inflammatory cytokine secretion. Int Immunopharmacol 5: 1820-1829

21. Bondet V, Brand-Williams W, Berset C (1997) Kinetics and mechanisms of antioxidant activity using the DPPH free radical method. LWT-Food Sci Technol 30: 609-615

22. Van den Berg R, Haenen GR, Van den Berg H, Bast A (1999) Applicability of an improved Trolox equivalent antioxidant capacity (TEAC) assay for evaluation of antioxidant capacity measurements of mixtures. Food Chem 66: 511-517

23. Oyaizu M (1986) Studies on products of browning reaction: antioxidative activities of products of browning reaction prepared from glucosamine. Jpn J Nutr 44: 307-315

24. AOAC (1995) Official Methods of Analysis (14th ed). Association of Official Analytical Chemists. 14th edn, Rockville, Maryland, pp 8-35

25. Que F, Mao L, Pan X (2006) Antioxidant activities of five Chinese rice wines and the involvement of phenolic compounds. Food Res Int 39: 581-587

26. Ferreira IC, Baptista P, Vilas-Boas M, Barros L (2007) Free-radical scavenging capacity and reducing power of wild edible mushrooms from northeast Portugal: Individual cap and stipe activity. Food Chem 100: $1511-1516$

27. Szabo C (1998) Role of nitric oxide in endotoxic shock. An overview of recent advances. Ann N Y Acad Sci 30: 422-425

28. 28. Martel-Pelletier J, Pelletier JP, Fahmi H (2003) Cyclooxygenase-2 and prostaglandins in articular tissues. Semin Arthritis Rheum 33: 155167

29. Weisz A, Cicatiello L, Esumi H (1996) Regulation of the mouse inducible-type nitric oxide synthase gene promoter by interferongamma, bacterial lipopolysaccharide and NG-monomethyl-L-arginine. Biochem J 316: 209-215

30. An SM, Kim HG, Choi EJ, Hwang HH, Lee ES, Baek JH, Boo YC, Koh JS (2014) Screening for anti-inflammatory activities in extracts from Korean herb medicines. J Soc Cosmet Sci Korea 40: 95-108

31. Kang CH, Choi YH, Choi IW, Lee JD, Kim GY (2011) Inhibition of lipopolysaccharide-induced iNOS, COX-2, and TNF- $\alpha$ expression by aqueous extract of Orixa japonica in Raw 264.7 cells via suppression of NF- $\kappa$ B activity. Trop J Pharm Res 10: 161-168

32. Hur GM, Ryu YS, Yun HY, Jeon BH, Kim YM, Seok JH, Lee JH (1999) Hepatic ischemia/reperfusion in rats induces iNOS gene transcription by activation of NF-kappaB. Biochem Biophys Res Commun 261: 917-922

33. Sato T, Nakajima H, Fujio K, Mori Y (1997) Enhancement of prostaglandin E2 production by epidermal growth factor requires the coordinate activation of cytosolic phospholipase A2 and cyclooxygenase 2 in human squamous carcinoma A431 cells. Prostaglandins 53: 355369

34. Huang M, Stolina M, Sharma S, Mao JT, Zhu L, Miller PW, Dubinett SM (1998) Non-small cell lung cancer cyclooxygenase-2-dependent regulation of cytokine balance in lymphocytes and macrophages : upregulation of interleukin 10 and down-regulation of interleukin 12 production. Cancer Res 58: 1208-1216 